\title{
KETIADAAN FUNGSI ASAS LEGALITAS DALAM HUKUM PIDANA UNTUK MELINDUNGI KEPENTINGAN KORBAN
}

\author{
Deni SB Yuherawan \\ Fakultas Hukum Universitas Trunojoyo Madura \\ Kampus Unijoyo, Telang, PO. BOX 2 Kamal - Bangkalan \\ Email: deniyuherawan@gmail.com
}

\begin{abstract}
In practical terms, Principle of Legality perform the function of protection and functionality limitations. The main problems principle of legality is of the absence of protection for victims. The absence of these functions is a logical consequence of the idea of the basic principle of legality in the form of guaranteed protection of the rights of citizens, by limiting the king's power and authority of judges through the instrument of criminal law. Reasons and the main purpose of this idea is to prevent citizens from criminal justice implementation arbitrary. In the life of the law, the legality principle which should give equal protection, was not able to provide protection against the public interest. In ethical life, the legality principle as a principle of law that is supposed to be in the public interest, it turns out more priority to the interests of offenders.
\end{abstract}

Key words: principle of legality, protection function, interests of victims

\begin{abstract}
Abstrak
Secara praktis, Asas Legalitas melakukan fungsi perlindungan dan fungsi pembatasan. Problema utama Asas Legalitas adalah ketiadaan perlindungan terhadap kepentingan korban. Ketiadaan fungsi tersebut merupakan konsekuensi logis dari gagasan dasar Asas Legalitas berupa jaminan perlindungan hak-hak warga negara, dengan cara membatasi kekuasaan raja serta kewenangan hakim melalui instrumen undang-undang pidana. Alasan dan tujuan utama gagasan ini untuk menghindarkan warga negara dari pelaksanaan peradilan pidana yang sewenang-wenang. Dalam kehidupan hukum, Asas Legalitas yang seharusnya memberikan perlindungan yang seimbang, ternyata tidak mampu memberikan perlindungan terhadap kepentingan masya rakat. Dalam kehidupan etis, Asas Legalitas sebagai suatu asas hukum yang seharusnya lebih mengutamakan kepentingan masyarakat, ternyata lebih mengutamakan kepentingan pelaku.
\end{abstract}

Kata kunci: asas legalitas, fungsi perlindungan, kepentingan korban

\section{Latar belakang}

Asas Legalitas (Legaliteit Beginsel) dalam hukum pidana dirumuskan dalam adagium:nullum delictum nulla poena sine praevea lege poenali (tiada delik, tiada pidana, tanpa undang-undang pidana terlebih dahulu). Asas Legalitas diwujudkan menjadi aturan hukum dalam Kitab Undang-undang Hukum Pidana (selanjutnya disebut KUHP) yakni Pasal 1 ayat (1)yang menentukan: 
"Tiada suatu perbuatan dapat dipidana kecuali atas kekuatan aturan pidana dalam perundangundangan yang telah ada". Ketentuan tersebut selaras dengan rumusan Pasal 1 ayat (1) Wetboek van Strafrecht (KUHP Belanda), yang menentukan:"Geen feit is strafbaar dan uit kracht van eene daaran voorafgegane wettelijke strafbepaling" (terjemahan bebas: tiada suatu perbuatan dapat dipidana kecuali atas kekuatan ketentuan pidana dalam undangundang yang ada lebih dahulu).

Keberadaan undang-undang pidana yang sudah harus ada terlebih dahulu sebelum perbuatan dilakukan berdampak kepada 2 (dua) hal esensial. Pertama, suatu perbuatan dikualifikasikan sebagai perbuatan pidana jika dilarang oleh undang-undang pidana. Seseorang hanya dapat dituntut jika melakukan perbuatan pidana. Secara a contrario, seseorang tidak dapat dituntut, jika perbuatannya belum dan/atau tidak dilarang oleh undang-undang pidana. Kedua, undang-undang pidana yang digunakan untuk menuntut suatu perbuatan adalah undang-undang pidana yang sudah ada sebelum perbuatan dilakukan. Dilarang memberlakukan undang-undang pidana yang dibuat setelah perbuatan tersebut dilakukan.

Esensi Asas Legalitas tersebut berdampak pada timbulnya 2 (dua) larangan dalam Asas Legalitas serta aturan hukum yang memanifestasikan Asas Legalitas, yaitu:

a. Kecuali pembuat undang-undang pidana (badan legislatif), siapa saja dilarang mengkualifikasikan suatu perbuatan sebagai perbuatan pidana. Hanya undang-undang pidana yang dapat mengkualifikasikan suatu perbuatan sebagai perbuatan pidana. Larangan inilah yang dikenal sebagai prinsip non-analogi, yakni larangan mengkualifikasikan suatu perbuatan sebagai perbuatan pidana di luar yang dilarang oleh undang-undang pidana; dan

b. Dilarang memberlakukan undang-undang pidana yang dibuat setelah perbuatan dilakukan (ex post facto penal law). Yang harus diberlakukan adalah undangundang pidana yang sudah ada saat perbuatan dilakukan (existing penal law). Larangan inilah yang dikenal dengan prinsip non-retroaktif, yakni dilarang memberlakukan undang-undang pidana secara retroaktif.

Esensi Asas Legalitas tersebut sangat berpengaruh kepada fungsi yang dilakukan oleh Asas Legalitas. Secara praksis, Asas Legalitas melakukan 2 (dua) fungsi yaitu:

a. Fungsi perlindungan: pelaku tidak akan dituntut secara pidana jika melakukan perbuatan yang tidak dilarang oleh undang-undang pidana, walaupun perbuatan tersebut merupakan perbuatan yang patut dipidana (strafwaardig). Asas Legalitas melindungi warga negara dari tuntutan secara pidana yang sewenangwenang; dan

b. Fungsi pembatasan: membatasi kewenangan penyidik, penuntut umum dan hakim, yang mana mereka tidak boleh mengkualifikasikan suatu perbuatan 
sebagai perbuatan pidana, selain perbuatan-perbuatan yang dilarang oleh undang-undang pidana.

Fungsi Asas Legalitas menjadi perhatian Schaaffmeister dan kawan-kawan yang menyatakan, berlakunya Asas Legalitas bertujuan agar undang-undang pidana melindungi rakyat dari pelaksanaan kekuasaan yang tanpa batas dari pemerintah. Ini yang dinamakan fungsi melindungi dari undang-undang pidana. Di samping fungsi melindungi, undang-undang pidana juga mempunyai fungsi instrumental yaitu pelaksanaan kekuasaan pemerintah tegastegas diperbolehkan dalam batas-batas yang ditentukan oleh undang-undang. ${ }^{1}$ Dari pendapat tersebut dapat disimpulkan bahwa pelaksanaan kekuasaan pemerintah untuk menuntut suatu perbuatan harus dalam batasbatas yang ditentukan oleh undang-undang. Dalam arti dalam batas perbuatan-perbuatan yang dilarang oleh undang-undang pidana. Suatu perbuatan yang berada di luar batasbatas yang dilarang undang-undang pidana tidak dapat dituntut. Fungsi instrumental ini ternyata juga hanya diabdikan untuk kepentingan pelaku, dimana kekuasaan pemerintah (dalam hal ini dilaksanakan oleh aparatur penegak hukum) tidak dapat menuntut perbuatan-perbuatan di luar batas yang dilarang oleh undang-undang pidana.
Menganalisis fungsi yang dilakukan Asas Legalitas, ternyata tidak memberikan perlindungan sama sekali terhadap korban. Atas nama Asas Legalitas, negara melalui aparatur penegak hukumnya ternyata tidak dapat melindungi kepentingan korban, walaupun mereka menderita kerugian moril dan materiil yang luar biasa. Sebuah ironi dalam hukum pidana, dimana kepentingan korban yang seharusnya dilindungi oleh hukum pidana, untuk dan atas nama Asas Legalitas ternyata diabaikan dan dinegasikan begitu saja.

Pengabaian dan penegasian perlindungan kepentingankorbandapatdiilustrasikansebagai tindakan belah bambu, dimana perlindungan terhadap pelaku ditarik semaksimal mungkin ke atas untuk dilindungi, tetapi menginjak perlindungan terhadap korban semaksimal mungkin ke bawah untuk diabaikan. Pada satu sisi, fungsi Asas Legalitas menghormati sepenuhnya kepentingan pelaku, sedang pada sisi lain telah menegasikan dan mengabaikan kepentingan korban.

Aspek perlindungan sepenuhnya terhadap pelaku pernah dikritik oleh E. Utrecht yang menyatakan, asas tersebut mengakibatkan banyak sekali perbuatan yang sepatutnya dipidana (strafwaardig) malah tidak dipidana serta menghalangi berlakunya hukum pidana adat yang masih hidup dan akan hidup. ${ }^{2}$ Kritik

1 Schaffmeister et al, Hukum Pidana, diedit oleh Sahetapy, Konsorsium Ilmu Hukum Departemen Konsorsium Ilmu Hukum Departemen P\&K, Liberty, Jogyakarta, 1995, hlm. 4

2 Andi Hamzah (selanjutnya disebut Andi Hamzah I), Asas-Asas Hukum Pidana, Edisi Revisi 2008, Rineka Cipta, Jakarta, 2008, hlm. 43. Pendapat yang sama juga disampaikan oleh Loeby Loqman dalam makalahnya: Perkembangan Asas Legalitas Dalam Hukum Pidana Indonesia, Seminar tentang Asas-Asas Hukum Pidana Nasional, diselenggarakan oleh Badan Pembinaan Hukum Nasional Departemn Kehakiman dan Hak Asasi Manusia RI bekerjasama dengan Fakultas Hukum Universitas Diponegoro Semarang, 26-27 April 2004, hlm. 9 
tersebut ditujukan terhadap perlindungan sepenuhnya Asas Legalitas terhadap kepentingan pelaku, sekaligus penegasian dan pengabaian perlindungan kepentingan korban.

Problematika utama dalam diri Asas Legalitas adalah ketiadaan fungsi perlindungan terhadap kepentingan korban. Ketiadaan fungsi tersebut menjadi perhatian Nyoman Serikat Putrajaya yang berpendapat, Asas Legalitas yang pada intinya berisi asas lex temporis delicti hanya memberikan perlindungan kepada individu pelaku dan kurang memberikan perlindungan kepada masyarakat/kelompok masyarakat yang menjadi korban tindak pidana, sehingga akses untuk memperoleh keadilan bagi korban terutama korban kolektif terhambat. ${ }^{3}$ Bagi Nyoman Serikat Putrajaya, ketiadaan fungsi perlindungan terhadap kepentingan korban benar-benar merupakan hambatan bagi para korban untuk mengakses keadilan.

Berdasarkan uraian di atas, dapat dirumuskan permasalahan yang menjadi isu hukum dalam artikel ini, yaitu: mengapa asas legalitas sama sekali tidak melakukan fungsi perlindungan terhadap korban?

\section{Pembahasan}

\section{A. Gagasan Dasar Asas Legalitas}

Secara esensial, gagasan dasar (basic ideas) Asas Legalitas adalah memberikan jaminan perlindungan hak-hak warga negara, dengan cara membatasi kekuasaan raja serta kewenangan hakim melalui instrumen undang-undang pidana. Warga negara tidak dapat dituntut secara pidana jika tidak melakukan perbuatan yang secara definitif dilarang oleh undang-undang pidana. Tujuan utama gagasan ini adalah menghindarkan warga negara dari peradilan pidana yang sewenang-wenang (arbitrer) yang dilakukan oleh raja melalui para hakim. Gagasan dasar ini berdampak pada munculnya konsep bahwa raja (cq. Hakim) dilarang menuntut perbuatan selama perbuatan tersebut belum dan/atau tidak dilarang oleh undang-undang pidana.

Pada umumnya diskursus tentang gagasan dasar Asas Legalitas selalu dikaitkan dengan peristiwa fenomenal yakni Revolusi Perancis (1789). Pendapat ini sangatlah wajar, karena gagasan dasar ini merupakan salah satu motif, tujuan dan agenda penting dalam Revolusi Perancis. Namun demikian, hal penting yang perlu dipahami bahwa gagasan dasar dari Asas Legalitas telah berabad-abad mewarnai lintasan sejarah peradilan pidana di Inggris jauh sebelum terjadinya Revolusi Perancis.

Magna Charta (Piagam Agung) 1215 di Inggris, yang dokumen aslinya bernama The Great Charter of English liberty granted (under considerable duress), yang ditandatangani oleh King John, telah menginisiasi gagasan dasar Asas Legalitas. Pasal 39 Magna Charta menentukan: No freeman shall be taken, or imprisoned, or disseized, or outlawed, or exiled, or in any way

3 Nyoman Serikat Putrajaya, Pemberlakuan Hukum Pidana Secara Retroaktif sebagai Penyeimbang Asas Legalitas dan Asas Keadilan (Suatu Pergeseran Paradigma dalam Ilmu Hukum Pidana), Pidato Pengukuhan Guru Besar, Universitas Diponegoro Semarang, 7 Agustus 2004, hlm. 37. 
harmed--nor will we go upon or send upon him-save by the lawful judgment of his peers or by the law of the land. Ketentuan pasal ini menegaskan bahwa tidak seorangpun dapat dikenakan tindakan penangkapan, penahanan, pemidanaan, penyitaan, dan pembuangan, kecuali ada putusan pengadilan yang sah atau oleh undang-undang. Gagasan dasar Magna Charta (1215) adalah jaminan perlindungan hak-hak-hak warga negara dan pembatasan kekuasaan raja dan hakim.

Bill of Rights (1628) juga memberikan jaminan perlindungan bagi hak-hak warga negara. Dokumen tersebut berisikan penegasan tentang pembatasan kekuasaan raja, seperti: memenjarakan, menyiksa dan mengirimkan tentara, tanpa dasar hukum. ${ }^{4}$ Gagasan dasar Bill of Rights (1628)adalah pembatasan kekuasaan raja dengan tujuan melindungi hak-hak warga negara.

Pada tahun 1679 di Inggris, dibuatlah Habeas Corpus Act yaitu undang-undang tentang "for the better securing the liberty of the subject, and for prevention of imprisonments beyond the seas", yang pada prinsipnya mengatur tentang perlindungan terhadap kebebasan warga negara Inggris dan pencegahan pemidanaan yang sewenangwenang.

Tidak terdapat perbedaan secara substansial di antara Magna Charta (1215), Bill of Rights (1628) dan Habeas Corpus Act (1679). Perbedaannya hanya pada tataran pengaturannya. Jika Magna Charta (1215) dan Bill of Rights (1628) berupa piagam dan rancangan undang-undang, maka Habeas Corpus Act (1679) berupa undang-undang. Peningkatan tataran pengaturan gagasan dasar tersebut semakin menegaskan tentang urgensi dan signifikansi jaminan perlindungan hak-hak warga negara, dengan cara membatasi kekuasaan raja dan kewenangan hakim. Dengan dibuatnya Habeas Corpus Act (1679), dapat dikatakan bahwa gagasan dasar tentang Asas Legalitas di Inggris sudah mencapai titik kulminasi.

Sekedar perbandingan, pada abad 17 di Perancis berlaku peradilan pidana yang dinamakan arbitrium judicis (pendapat hakim), suatu peradilan pidana yang ditandai dengan kewenangan hakim untuk mengkualifikasikan perbuatan pidana. Pada abad tersebut, gagasan dasar Asas Legalitas belum tumbuh di Perancis. Pada awalnya, peradilan pidana yang dimulai pada abad 16 , tidak banyak menimbulkan persoalan bagi warga negara Perancis. Tetapi, mulai awal sampai pertengahan abad 18 , peradilan pidana ini mulai dilaksanakan secara sewenangwenang oleh hakim, sebagai akibat tekanan luar biasa dari raja yang berkuasa. Dalam kurun waktu ini, peradilan arbitrium judicis dilakukan secara arbitrer.

Gagasan dasar dari Asas Legalitas juga menjadi diskursus para pemikir Inggris, seperti John Locke, David Hume dan Francois

4 Majda El-Muhtaj, Hak Asasi Manusia dalam Konstitusi Indonesia, Kencana Prenada Media Group, Jakarta, 2005, hlm. 52 . 
Bacon. Gagasan penting John Locke adalah:

1. Menolak faham staatsrason (kedaulatan negara);

2. Menolak semua kekuasaan yang tidak mengindahkan hak-hak alam pada setiap manusia. Hak-hak ini tidak dapat diganggu oleh siapa pun, meskipun dia seorang kepala negara;

3. Mewajibkan negara untuk menjaga hak-hak warga negara;

4. Yang harus menjaga agar hak-hak pribadi dipertahankan adalah negara dan tata hukum;

5. Mendasarkan konsep negara hukum pada konsep pokok: negara harus menjaga hak-hak warga negara. Untuk melaksanakan tugas dan fungsinya, penguasa negara tidak boleh sewenangwenang. Oleh karena itu, kekuasaan negara harus diatur oleh undang-undang yang tetap (standing law) dan bukan oleh dekrit (arbitrary decrees);

6. negara hukum bukan hanya menjaga aturan hukum, melainkan wahana perwujudan dan perkembangan aturan hidup berdasarkan prinsip-prinsip hukum; dan

7. Pembagian kekuasaan negara. ${ }^{5}$

Penolakan terhadap faham staatsrason; mewajibkan negara menjaga hak-hak asasi warga negara, membagi kekuasaan negara, dan pembatasan kekuasaan negara melalui konsep negara hukum dengan tujuan utama memberikan jaminan perlindungan hak-hak asasi warga negara, secara esensial merupakan pembatasan kekuasaan penguasa. Gagasan negara dan tata hukum sebagai pengawal hak-hak asasi warga negara, serta konsep negara hukum secara esensial merupakan perlindungan hak-hak asasi warga negara. Gagasan tentang keharusan membatasi kekuasaan penguasa negara dan perlindungan hak asasi warga negara dengan menggunakan instrumen undang-undang, secara esensial menempatkan undang-undang (pidana) pada posisi sentral dalam kehidupan bernegara.

Selaras dengan gagasan John Locke, David Hume menolak keabsolutan negara dan hak ilahi pada raja. Kekuasaan dalam negara memang ada, tetapi kekuasaan tersebut tidak berakar dalam asalnya yang historis, melainkan dalam kegunaannya yang konkrit bagi masyarakat. ${ }^{6}$ David Hume menolak keberlakuan dalil yang menyatakan bahwa raja mempunyai kekuasaan yang absolut, kekuasaan yang merupakan amanah dan perintah Tuhan. Kekuasaan raja seharusnya ditujukan untuk kemanfaatan hidup bernegara.

Sebelum John Locke dan David Hume mengemukakan gagasan mereka, Francis Bacon sudah berpendapat tentang urgensi dan signifikansi undang-undang pidana dalam peradilan pidana. Francis Bacon mengemukakan adagium: moneat lex, priusquam feriat" (undang-undang harus memberikan peringatan terlebih dahulu

5 Theo Huijbers(selanjutnya disebut Theo Huijbers I), Filsafat Hukum dalam Lintasan Sejarah, Kanisius, Jogyakarta, 1982, hlm. 80-84.

6 Ibid, hlm. 84-85. 
sebelum merealisasikan ancaman yang terkandung di dalamnya). ${ }^{7}$ Gagasan Francis Bacon menegaskan bahwa perbuatan dan ancaman pidana harus diatur dalam undangundang yang harus dibuat terlebih dahulu sebelum diberlakukan.

Menganalisis gagasan yang dikemukan oleh John Locke, David Hume dan Francois Bacon, dapat disimpulkan bahwa bagi ketiga pemikir tersebut, jaminan perlindungan hak-hak asasi warga negara, dengan cara membatasi kekuasaan raja dan kewenangan hakim melalui instrumen undang-undang pidana merupakan urgensi yang tidak dapat ditawar-tawar lagi.

Pemikiran tentang gagasan dasar dari Asas Legalitas tersebut mempengaruhi para pemikir Perancis seperti Charles-Louis Montesquieu dan Jean Jacques Rousseau. Menjelang Revolusi Perancis (1789), gagasangagasan yang dikembangkan para pemikir ini menjadi bahan bakar yang menyulut tekad dan semangat rakyat Perancis untuk menolak keabsolutan kekuasaan raja yang selalu berlindung di balik semboyan Letat ces moi (state is me atau negara adalah aku), juga untuk menolak kesewenang-wenangan hakim dalam peradilan pidana arbitrium judicis.

Montesquieu menolak keras kekuasaan raja dan kewenangan hakim yang absolut, sebagaimana direpresentasikan pada pelaksanaan peradilan pidana arbitrium judicis. Menurut Peter Mahmud Marzuki bahwa begitu absolutisme tumbuh pesat pada ancien regime, terdapat tuntutan mengenai perlindungan hukum bagi warga negara dari kekuasaan raja yang bersifat abosolut. Montesquieu memperkenalkan doktrin pemisahan kekuasaan, yang oleh Immanuel Kant disebut Trias Politica. Menurut doktrin tersebut, tugas hakim terbatas pada penerapan hukum yang dibuat oleh kekuasaan legislatif. ${ }^{8}$

Tentang ajaran trias politica, Theo Huijbers berpendapat bahwa ajaran tersebut sebenarnya sudah dirintis oleh John Locke. John Locke menyatakan bahwa kekuasaan negara dibagi menjadi kekuasaan legislatif, eksekutif dan federatif. Namun kekuasaan federatif sangat sulit dibedakan dari kekuasaan eksekutif, sehingga sebenarnya hanya tinggal 2 (dua) kekuasaan saja. Montesquieu berjasa menambah kekuasaan yang ketiga yaitu kekuasaan yudisial, sebagai kekuasaan yang berbeda dari kekuasaan yang lain. Kekuasaan yudisial berarti seorang hakim harus berdaulat dalam bidangnya, di mana pemimpin negara tidak berhak untuk campur tangan dalam bidang ini. Prinsip kedaulatan kekuasaan yudisial sangat mendorong perkembangan negara hukum. ${ }^{9}$

Hakim memang mempunyai kekuasaan yang berdaulat di bidang yudisial, tetapi tidak mempunyai kewenangan untuk mengkualifikasikan suatu perbuatan sebagai

7 ELSAM, Rancangan KUHP, cetakan pertama, Jakarta, 2005.

8 Peter Mahmud Marzuki, Pengantar Ilmu Hukum, Kencana Prenada Media Group, Jakarta, 2008, hlm. 216.

9 Theo Huijbers I, Op.Cit., hlm. 87. 
perbuatan pidana, sebagaimana kewenangan hakim pada peradilan pidana arbitrium judicis di masa ancien regime. Bagi Montesquieu, yang berwenang mengkualifikasikan perbuatan pidana adalah kekuasaan legislatif.

Kekuasaan legislatif dalam bidang hukum pidana, tidak saja menetapkan norma, tetapi juga harus mengumumkan sebelum perbuatan. $^{10}$ hakim hanya sebagai penerap undang-undang tersebut. Montesquieu berargumentasi, bahwa les juges de la nation ne sont qu la bouche qui prononce les paroles de la loi; des etres inanimes qui nen peuvent moderer ni la force ni la rigueur. Para hakim hanyalah mulut yang mengucapkan kata-kata undang-undang. Mereka adalah makhlukmakhluk tidak bernyawa yang tidak boleh melemahkan kekuatan dan kekerasan undangundang. Preposisi inilah yang akhirnya dikenal dengan semboyan hakim adalah corong undang-undang. Secara esensial, gagasan Montesquieu adalah pembatasan kekuasaan raja dan kewenangan hakim.

John Gilissen dan Frits Gorle berpendapat, Montesquieu telah mempelajari secara mendalam institusi-intitusi di Inggris dan memberikan respek terhadap konsep pemisahan kekuasaan dan kebebasan politik yang berlaku di Inggris sejak revolusi tahun 1688. ${ }^{11}$ Bagi John Gilissen dan Frits Gorle, pada intinya Montesquieu mengajarkan tentang:

a. Agar dapat mempertahankan kebebasan diperlukan pemisahan kekuasaan yakni kekuasaan legislatif, kekuasaan eksekutif, dan kekuasaan yudisial, disertai tatanan pengawasan dan keseimbangan timbal balik (checks and balances), dan

b. Aturan-aturan ini (undang-undang) harus sederhana, sesuai dengan rasio dan rasa keadilan dan dapat dimengerti oleh setiap warga negara. ${ }^{12}$

Dapat disimpulkan, gagasan yang dikembangkan Montesquieu adalah perlindungan hak-hak warga negara, dengan membatasi kekuasaan raja dan kewenangan hakim berdasarkan pemisahan kekuasaan, yang diatur oleh instrumen undang-undang.

Rousseau menginginkan tatanan masyarakat baru, suatu masyarakat di mana individu dapat hidup sesuai dengan martabat dan kebebasannya. Gagasan Rousseau yang terkenal yaitu: kontrak sosial, manusia adalah makhluk yang bebas dan otonom, volonte generale (kehendak umum), dinteret commun (kepentingan umum), dan kedaulatan rakyat.

Bagi Rousseau, keberadaan volonte generale dan dinteret commun mengakibatkan munculnya konsep kedaulatan rakyat. Kekuasaan rakyat adalah berdaulat, sebagai kekuasaan yang mutlak, suci, dan kebal. Kekuasaan rakyat meliputi semua bidang

10 Andi Hamzah, (selanjutnya disebut And Hamzah II), Perbandingan Hukum Pidana Beberapa Negara, Edisi Ketiga, Sinar Grafika, Jakarta, 2008, hlm. 41.

11 Glissen, John and Frits Gorle, Sejarah Hukum: Suatu Pengantar, disadur oleh Freddy Tengker, Refika Aditama, Bandung, 2009, hlm. 119.

12 Ibid., hlm. 120. 
hidup, juga merupakan sumber kekuatan hukum yang menjamin kebebasan dan kesamaan individu. ${ }^{13}$ Gagasannya tersebut dilanjutkan dengan gagasannya tentang urgensi undang-undang dalm hidup bernegara.

Menurut Rousseau, kehidupan bernegara harus diatur oleh undang-undang, karena undang-undang merupakan perwujudan dari volonte generale, dan bukan lagi sekedar kehendak raja. Undang-undang pada hakikatnya adalah une declaration publique et solennelle de la volunte generale sur un objet dinteret commun. ${ }^{14}$ Secara esensial, undangundang adalah perwujudan volunte genarale (kehendak umum) dan dinteret commun (kepentingan umum). Secara a contrario, Rousseau menolak kehidupan bernegara dan bermasyarakat yang didasarkan pada perintah (titah) raja.

Gagasan Rousseau adalah perlunya perlindungan hak-hak warga negara, dengan membatasi kekuasaan raja (termasuk kewenangan hakim) berdasarkan kedaulatan rakyat melalui instrumen undang-undang, sebagai perwujudan volonte generale, dinteret commun, dan kedaulatan rakyat.

Terdapat benang merah gagasan yang dikemukakan oleh Montesquieu dan Rousseau. Gagasan kedua pemikir tersebut menunjukkan bahwa sangat penting adanya perlindungan hak-hak warga negara dengan cara membatasi kekuasaan raja dan kewenangan hakim melalui pemisahan kekuasan (sebagai akibat eksistensi kedaulatan rakyat) dengan menggunakan instrumen undang-undang. Gagasan-gagasan kedua pemikir ini semakin menegaskan signifikansi eksistensi Asas Legalitas.

Menjelang Revolusi Perancis, gagasan dasar tentang Asas Legalitas tersebut diatur dalam Pasal 8 Declaration des droits de Lhomme et $d u$ citoyen (1789) yang menentukan: "La Loi ne doit établir que des peines strictement et évidemment nécessaires, et nul ne peut être puni quen vertu dune Loi établie et promulguée antérieurement au délit, et légalement appliquée". Ketentuan pasal ini menegaskan bahwa diperlukan undangundang yang dinyatakan dengan tegas dan jelas, dan tidak ada yang dapat dipidana kecuali oleh undang-undang yang dibuat dan diumumkan sebelum pelanggaran. Keharusan adanya undang-undang pidana yang tegas dan memberlakukan undang-undang pidana yang berlaku pada saat perbuatan dilakukan merupakan prasyarat penting dari sistem peradilan pidana baru yang dicita-citakan rakyat Perancis.

Setelah revolusi, substansi Pasal 8 Declaration des droits de Lhomme et du citoyen, diatur kembali pada Pasal 4 Code Penal Perancis yang menentukan:"Nulle contravention, nul delit, nul crime ne peuvent etre punis de peinesqui netaient pas prononcees par la loi avant quils fussent commis". Pasal ini menentukan bahwa tiada 
delik, tiada kejahatan jika tidak ada ancaman pidana yang dinyatakan dalam undang-undang terlebih dahulu.

\section{B. Keterbatasan-Keterbatasan \\ Legalitas}

Asas

Sejak masih berupa gagasan sampai dimanifestasikan ke dalam Pasal 8 Declaration des droits de Lhomme et du citoyen dan Pasal 4 Code Penal Perancis, alasan dan tujuan utama Asas Legalitas adalah memberikan jaminan perlindungan hak-hak warga negara dengan cara membatasi kekuasaan penguasa dan kewenangan hakim melalui instrumen undang-undang pidana. Hakikat Asas Legalitas adalah sintesis antara perlindungan hak-hak warga negara, pembatasan kekuasaan penguasa dan kewenangan hakim, serta undang-undang pidana. Landasan ontologis Asas Legalitas adalah undang-undang pidana beserta perbuatan pidana yang diaturnya, sedang landasan aksiologisnya adalah perlindungan hak-hak warga negara.

Undang-undang pidana sebagai landasan ontologis Asas Legalitas menempatkannya sebagai pondasi sistem hukum pidana dan peradilan pidana. Sistem hukum pidana harus didasarkan pada undang-undang pidana (hukum pidana tertulis). Sistem hukum pidana tidak mengenal hukum pidana tidak tertulis. Hukum pidana harus dipahami sebagai hukum undang-undang (statute law). Hukum undang-undang merupakan syarat mutlak (conditio sine qua non) keberadaan sistem hukum pidana. Demikian juga dengan peradilan pidana, peradilan harus dilaksanakan berdasarkan undang-undang pidana. Preposisi yang tepat untuk mengilustrasikan keterkaitan antara undang-undang pidana, sistem hukum pidana, dan peradilan pidana adalah: tiada hukum pidana dan peradilan pidana tanpa undang-undang pidana.

Posisi sentral undang-undang pidana meyebabkan situasi bahwa hanya undangundang pidana yang dapat mengkualifikasikan perbuatan pidana dan ancaman pidana. Perbuatan yang dijadikan dasar tuntutan hanyalah perbuatan yang dilarang oleh undang-undang pidana (mala prohibita), begitu juga dengan ancaman pidana yang akan diterapkan hanyalah ancaman pidana yang diatur oleh undang-undang pidana. Implikasinya, perbuatan yang patut dipidana (strafwaardig) tidak dapat dituntut secara pidana, karena bukan perbuatan yang dilarang oleh undang-undang pidana.

Landasan ontologis Asas Legalitas mengakibatkan munculnya keterbatasan dalam diri Asas Legalitas, yaitu ketidakberdayaan menuntut perbuatan strafwaardig, meskipun perbuatan tersebut menimbulkan kerugian luar biasa bagi korban. Keterbatasan daya jangkau Asas Legalitas untuk menuntut perbuatan strafwaardig yang menimbulkan kerugian luar biasa, telah menempatkan kepentingan korban di bawah kepentingan pelaku. Dengan kata lain, mengabaikan kepentingan korban (yang seharusnya dilindungi) demi menjunjung tinggi kepentingan pelaku. 
Secara ontologis, Asas Legalitas hanya diorientasikan terhadap kepentingan pelaku (offender oriented). Pelaku yang tidak melakukan mala prohibita dan hanya melakukan perbuatan strafwaardig tidak akan dituntut. Asas Legalitas hanya memberikan nilai manfaat kepada pelaku. Secara aksiologis, nilai manfaat Asas Legalitas hanya ditujukan kepada kepentingan pelaku. Asas Legalitas sama sekali tidak memberikan nilai manfaat bagi korban. Hal tersebut berakibat adanya keterbatasan Asas Legalitas yaitu mengabaikan bahkan menegasikan kepentingan korban.

Hal berikutnya yang menarik untuk dibahas adalah hubungan para pemangku kepentingan (stake holders) dalam konteks landasan ontologis Asas Legalitas. Undangundang pidana digunakan untuk membatasi kekuasaan penguasa dan kewenangan hakim dengan tujuan melindungi hak-hak individu warga negara dari pelaksanaan kekuasaan penguasa dan kewenangan hakim yang sewenang-wenang. Penguasa (melalui) hakim baru dapat menuntut suatu perbuatan jika perbuatan tersebut sudah dilarang oleh undang-undang pidana yang dibuat oleh badan legislatif. Jelas bahwa gagasan dasar Asas Legalitas dibangun atas dasar hubungan warga negara-penguasa. Penguasa (melalui aparatur penegak hukumnya) dapat melakukan tuntutan secara pidana jika pelaku melakukan mala prohibita dengan menggunakan undangundang pidana yang berlaku. Jika perbuatan pelaku bukan mala prohibita, maka penguasa (melaui aparatur penegak hukumnya) dilarang melakukan tuntutan secara pidana.

Dalam hal terjadinya mala prohibita, aspek perlindungan kepentingan korban baru diperhatikan jika ternyata penguasa (melalui aparatur penegak hukumnya) secara praksis melakukan penuntutan terhadap pelaku. Namun, jika penguasa (melalui aparatur penegak hukumnya) karena satu dan lain tidak melakukan penuntutan, perlindungan terhadap kepentingan korban akan terabaikan. Dalam konteks ini, bangunan Asas Legalitas didasarkan pada hubungan pelaku-penguasa. Hubungan pelaku-penguasa-korban baru terjadi jika penguasa menuntut pelaku. Nilai manfaat dari Asas Legalitas diberikan kepada korban, jika penguasa (melalui aparatur penegak hukumnya) benar-benar menuntut perbuatan pelaku.

Dalam terjadinya perbuatan strafwaardig, untuk dan atas nama Asas Legalitas maka penguasa (melalui aparatur penegak hukumnya) justru dilarang melakukan penuntutan. Korban justru dirugikan dengan keberadaan Asas Legalitas jika perbuatan yang dilakukan merupakan perbuatan strafwaardig. Dalam hal ini, hubungan pelaku-penguasakorban tidak akan pernah terjadi. Hal ini semakin menegaskan keterbatasan Asas Legalitas untuk melindungi kepentingan korban dalam hal terjadinya perbuatan strafwaardig.

Hal lain yang perlu dianalisis adalah pengabaian bahkan penegasian kepentingan masyarakat yang menjadi korban dari suatu 
perbuatan strafwaardig. Dalam hal ini, Asas Legalitas sama sekali tidak melakukan fungsi perlindungan terhadap kepentingan masyarakat. Meskipun masyarakat yang menjadi korban, Asas Legalitas sama sekali tidak diorientasikan untuk melindungi kepentingan masyarakat.

Perimbangan kepentingan masyarakat dan individu pelaku menjadi hal yang sangat penting untuk dianalisis. Penjelasan teoritis yang dapat digunakan untuk menganalisis adalah teori ko-eksistensi. Teori ini mengajarkan bahwa manusia hidup bersama dengan orang lain. Kebersamaan ini nyata dalam seluruh hidup manusia, dalam segala tindakannya. Beranjak dari diri sendiri ke arah sesama. ${ }^{15}$ Dalam hal ini, Heidegger menyusun preposisi: Sein ist Meitsein (ada selalu juga ada bersama) dan Das mitsein is ein existenziales konstituens des in-der-Welt-Sein (Ada bersama merupakan sifat eksistensial daripada berada di dunia). Terdapat 3 (tiga) tingkatan dalam ko-eksistensi, yaitu: ${ }^{16}$

a. Ko-eksistensi biologis-psikis, yang berdasarkan kebutuhan aku. Dalam keadaan ini, aku dipandang sebagai lebih tinggi daripada sesama;

b. Ko-eksistensi etis berdasarkan kesamaan hak. Dalam keadaan ini, aku dipandang sama tinggi dengan sesama. Prinsip rasional ini menjadi sumber hukum; dan

c. Ko-eksistensi etis berdasarkan kewajiban. Dalam hal ini, sesama dipandang lebih tinggi daripada aku. Prinsip ini menjadi sumber moral hidup, dan sumber hidup bersama bermoral, yakni aku mau tunduk kepada sesama manusia demi suatu kehidupan yang luhur sesuai dengan kehendak Tuhan.

Dalam konteks biologis-psikis, teori ko-eksistensi membenarkan jika kepentingan individu berada di atas kepentingan masyarakat. Dalam konteks ko-eksistensi etis berdasarkan kesamaan hak, teori ko-eksistensi mengajarkan bahwa kepentingan individu sejajar dengan kepentingan masyarakat. Tetapi dalam konteks ko-eksistensi etis berdasarkan kewajiban, kepentingan individu berada di bawah kepentingan masyarakat.

Kehidupan berhukum menempatkan kepentingan individu sejajar dengan kepentingan masyarakat, sehingga jika terjadi pelanggaran hukum yang dilakukan individu, maka kepentingan individu dan masyarakat harus diperlakukan secara setara. Dari perspektif demikian, Asas Legalitas telah memberikan perlindungan yang tidak proporsional, karena lebih melindungi kepentingan individu (pelaku) dibanding kepentingan masyarakat (korban).

Kehidupan beretika mengharuskan kita memahami bahwa siapa saja yang telah menimbulkan kerugian kepada pihak lain harus bertanggungjawab atas kerugian tersebut. Dalam kehidupan beretika kepentingan masyarakat harus lebih diutamakan dibanding

15 Theo Huijbers, (selanjutnya disebut Theo Huijbers II), Filsafat Hukum, Kanisius, Jogyakarta, 1995 hlm. 61. 16 Ibid., hlm. 63. 
kepentingan individu. Keterkaitan asas hukum, perlindungan individu (pelaku) dan masyarakat (korban) dalam kehidupan berhukum dan beretika dapat diilustrasikan dalam gambar berikut:

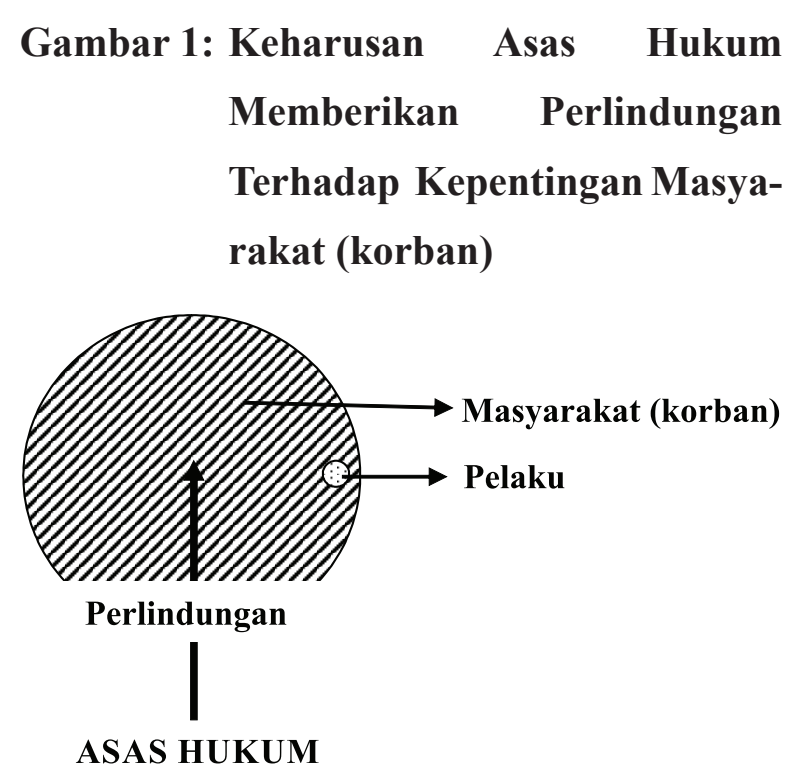

Sumber: Diolah

Gambar di atas menegaskan bahwa asas hukum seharusnya lebih berorientasi kepada perlindungan kepentingan masyarakat yang mempunyai tingkatan lebih tinggi dibandingakan kepentingan individu.

Dari perspektif ini, Asas Legalitas memberikan perlindungan yang sangat tidak proporsional, karena hanya berorientasi kepada perlindungan kepentingan individu (pelaku) dengan mengorbankan kepentingan masyarakat (korban). Ketidakproporsionalan Asas Legalitas dapat diilustrasikan dalam gambar berikut:
Gambar 2: Ketidak proporsionalan Asas Legalitas Memberikan Perlindungan Terhadap Kepentingan Masyarakat dan Kepentingan Individu

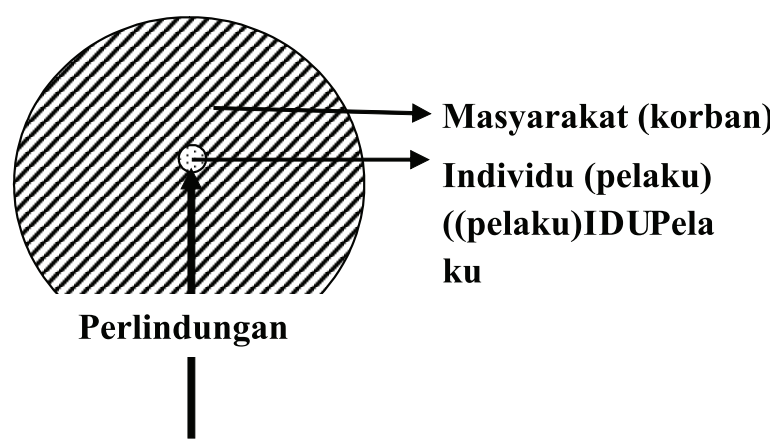

ASAS LEGALITAS

Sumber: Diolah

Gambar tersebut menegaskan bahwa Asas Legalitas hanya diorientasikan untuk melindungi kepentingan individu (pelaku) yang yang tingkatannya jauh lebih rendah dibandingkan kepentingan masyarakat (korban). Orientasi Asas Legalitas telah menempatkan kepentingan masyarakat (korban) dan individu (pelaku) pada posisi jungkir balik secara akrobatik.

\section{Simpulan}

Berdasarkan pembahasan terhadap isu hukum dapat disimpulkan bahwa Asas Legalitas, secara praksis sama sekali tidak melakukan fungsi perlindungan terhadap kepentingan korban (individu maupun masyarakat) karena adanya ketimpangan landasan ontologis dalam diri Asas Legalitas. Asas Legalitas yang secara ontologis bersubstansikan undang-undang pidana dan mala prohibita (perbuatan yang dilarang oleh undang-undang pidana) telah mengakibatkan keterbatasan-keterbatasan dalam dirinya, yaitu: 
1. Ketidakberdayaan melakukan penuntutan terhadap perbuatan strafwaardig (patut dipidana), walaupun menimbulkan kerugian luar biasa bagi korban, hanya karena belum atau tidak dilarang oleh undang-undang pidana. Ketidakberdayaan tersebut telah menempatkan kepentingan korban di bawah kepentingan pelaku. Asas Legalitas benar-benar mengabaikan dan menegasikan kepentingan korban, demi menghormati dan menjunjung tinggi kepentingan pelaku;

2. Ketidakberdayaan memberikan nilai manfaat bagi korban. Asas Legalitas hanya diorientasikan untuk melindungi kepentingan pelaku (offender oriented). Pelaku yang melakukan perbuatan strafwaardig, tidak akan dituntut. Secara aksiologis, dalam hal terjadi perbuatan strafwaardig, Asas Legalitas sama sekali tidak memberikan nilai manfaat bagi korban, meskipun korban menderita kerugian yang luar biasa;

3. Ketidakberdayaan membangun hubungan pelaku-penguasa-korban. Gagasan dasar Asas Legalitas dibangun didasarkan pada hubungan pelaku-penguasa. Penguasa (melalui aparat penegak hukum) dilarang menuntut pelaku jika pelaku hanya melakukan perbuatan strafwaardig, meskipun perbuatan tersebut telah menimbulkan kerugian luar biasa bagi korban. Dalam hal terjadinya perbuatan strafwaardig, hubungan pelaku-korbanpenguasa tidak akan pernah terjadi. Dalam hal terjadinya mala prohibita pun, hubungan pelaku-penguasa-korban baru terjadi jika penguasa benar-benar melakukan penuntutan terhadap pelaku. Tetapi jika karena satu dan lain hal, penguasa (melalui aparat penegak hukum) tidak menuntut pelaku yang melakukan mala prohibita, maka hubungan pelakupenguasa-korban juga tidak akan pernah terjadi;

4. Ketidakberdayaan melindungi kepentingan masyarakat yang menjadi korban dari perspektif ko-eksistensi etis berdasarkan kesamaan hak. Dari perspektif ini, dalam kehidupan hukum, kepentingan individu disejajarkan dengan kepentingan masyarakat. Dalam hal terjadi mala prohibita, seharusnya Asas Legalitas memberikan perlindungan secara proporsional terhadap kepentingan masyarakat dan pelaku. Ternyata Asas Legalitas tidak mampu memberikan perlindungan kepada kepentingan masyarakat;

5. Ketidakberdayaan melindungi kepentingan masyarakat yang menjadi korban dari perspektif ko-eksistensi etis berdasarkan kewajiban. Dari perspektif ini, dalam kehidupan etis, kepentingan masyarakat lebih tinggi tingkatannya dibandingkan dengan kepentingan pelaku. Dalam hal terjadi perbuatan strafwaardig, seharusnya suatu asas hukum lebih mengutamakan kepentingan masyarakat dibandingkan kepentingan pelaku. Tidak demikian halnya dengan Asas Legalitas. Asas Legalitas ternyata lebih mengutamakan kepentingan pelaku yang kedudukannya lebih rendah dibandingkan kepentingan masyarakat. 


\section{DAFTAR PUSTAKA}

\section{Buku}

Andi Hamzah, 2008, Asas-asas Hukum Pidana (Edisi Revisi 2008), Rineka Cipta, Jakarta.

2008, Perbandingan

Hukum Pidana Beberapa Negara,

Edisi Ketiga, Sinar Grafika, Jakarta.

Glissen, John and Frits Gorle, 2009, Sejarah

Hukum: Suatu Pengantar, Refika Aditama, Bandung.

Majda El-Muhtaj, 2005, Hak Asasi Manusia

dalam Konstitusi Indonesia, Kencana

Prenada Media Group, Jakarta.

Peter Mahmud Marzuki, 2008, Pengantar

Ilmu Hukum, Kencana Prenada Media Group, Jakarta.

Schaffmeister et al, 1995, Hukum Pidana

(diedit oleh Sahetapy), Konsorsium

Ilmu Hukum Departemen Konsorsium

Ilmu Hukum Departemen P\&K,

Liberty, Yogyakarta.

Theo Huijbers, 1982, Filsafat Hukum

dalam Lintasan Sejarah, Kanisius, Yogyakarta.
1995, Filsafat Hukum, Penerbit Kanisius, Jogyakarta.

\section{Makalah}

ELSAM, 2005, Rancangan KUHP, cetakan pertama, Jakarta.

Loeby Loqman, 2004, Perkembangan Asas Legalitas dalam Hukum Pidana Indonesia, Seminar tentang Asasasas Hukum Pidana Nasional tanggal 26-27 April 2004, diselenggarakan oleh Badan Pembinaan Hukum Nasional Departemn Kehakiman dan Hak Asasi Manusia RI bekerjasama dengan Fakultas Hukum Universitas Diponegoro Semarang.

Nyoman Serikat Putrajaya, 2004, Pemberlakuan Hukum Pidana secara Retroaktif sebagai Penyeimbang Asas Legalitas dan Asas Keadilan (Suatu Pergeseran Paradigma dalam Ilmu Hukum Pidana), Pidato Pengukuhan Guru Besar tanggal 7 Agustus 2004, Universitas Diponegoro Semarang. 